\title{
BIAS JENDER DALAM MATERI AJAR AQIDAH AKHLAK DI MADRASAH IBTIDAIYAH: Studi Analisis Bias Jender pada Bahasa dan Gambar
}

\author{
Siti Farikhah \\ Institut Agama Islam Negeri (IAIN) Salatiga \\ e-mail: siti.farikhah@gmail.com
}

\begin{abstract}
Abstrak
Penelitian ini bertujuan untuk mengidentifikasi bias jender pada gambar dan bahasa yang terdapat pada materi ajar Aqidah Akhlak di Madrasah Ibtidaiyah. Pemilihan buku ajar Madrasah Ibtidaiyah yang berperspektif jender adalah tindakan yang tepat, agar kekelinuan pola pikir kognitif dan bentukan afektif maupun psikomotoriknya tidak terlanjur jauh terinternalisasi dari kecakapan, sikap dan perilaku peserta didik. Jenis penelitian ini adalah kualitatif deskrptif. Populasi penelitian ini adalah buku ajar pada mata pelajaran Aqidah Akhlak kelas 1, 2, 3, 4, 5 dan 6 yang digunakan di Madrasah Ibtidaiyah di kota Salatiga, Kabupaten Magelang dan Kabupaten Ponorogo. Pengambilan sampel menggunakan teknik purposive random sampling, yaitu benupa buku ajar Aqidah Akhlak yang dikeluarkan oleh beberapa penerbit yang terbanyak digunakan MI di ketiga kota tersebut. Teknik pengumpulan data dilakukan dengan cara mengamati (observasi) secara cermat, yaitu mengidentifikasi ada tidaknya bias jender berdasarkan instrumen yang berupa lembar identifikasi bias jender yang berisi tentang paparan gambar-gambar dan kalimat-kalimat yang menunjukkan bias jender pada peran jender seperti peran produktif, reproduktif dan sosial. Teknik analisis data dalam penelitian ini menggunakan teknik analisis isi (content analysis), sarana tanda (signvechile) dan analisis wacana. Hasil penelitian terhadap gambar pada materi ajar Aqidah Akhlak mulai dari kelas 1 sampai dengan kelas 6, sebagian besar perempuan masih digambarkan pada gambar yang kecil dibandingkan dengan gambar jenis kelamin yang lain, diletakkan pada posisi dibelakang, masih mendapatkan peran yang kurang signifikan bahkan mendiskriditkan perempuan antara lain beberapa sikap negatif yang dilekatkan pada jenis kelamin perempuan. Pelabelan atau steriotipe terhadap perempuan bahwa perempuan itu makhluk yang lemah, marginalisasi terhadap perempuan sehingga banyak digambarkan bahwa perempuan hanya bertindak sebagai pelayan keluarga, istri yang hanya melayani suami dan anak-anaknya, subordinasi terhadap hak perempuan untuk menjadi anak yang pintar seperti juara kelas, sekolah, mencari nafkah masih jelas terlihat.
\end{abstract}


Selain itu frekuensi gambar yang sering muncul dimasing-masing pelajaran masih didominasi oleh laki-laki.

Kata Kunci: bias jender; Madrasah Ibtidaiyah; Aqidah Akhlak

\section{A. Pendahuluan}

Bias jender dalam pendidikan dapat ditemui pada jenjang, jenis, dan satuan pendidikan. Secara khusus bias jender terjadi pada jenjang pendidikan dasar. Komponen bias jender pada pendidikan dasar dapat dicermati pada aspek kurikulum, buku ajar, metode pembelajaran, penentu kebijaksanaan, kegiatan ekstrakurikuler. ${ }^{1}$ Bias jender juga terjadi pada hampir semua buku pelajaran pada jenjang pendidikan dasar sampai dengan tingkat pendidikan menengah seperti dalam Aqidah Akhlak untuk Madrasah Ibtidaiyah (MI) dalam bentuk gambar maupun dalam kalimat yang ada dalam materi pelajaran tersebut. Bias jender muncul baik dari segi intensitas munculnya gambar dan kalimat, penokohan, dan peran yang dibawakan. Peran perempuan diilustrasikan sangat terbatas dalam buku-buku pelajaran tersebut dan cenderung menampilkan anak laki-laki pada gambar-gambar maupun ilustrasinya. Peran domestik selalu diilustrasikan dengan anak perempuan, sedangkan kegiatan publik selalu diilustrasikan dengan laki-laki. Dengan demikian, terdapat pembagian peran jender seperti peran produktif, reproduktif, dan sosial yang tidak setara dan adil. Terdapat juga stereotipe jender seperti sifat perilaku jender, nilai jender, dan status jender sebagai suatu pelabelan atau bentuk generalisasi perilaku individu-individu dari anggota kelompok tertentu, baik itu menurut suku bangsa, bangsa, dan/ atau jenis kelamin dengan pelabelan tersebut yang belum tentu benar.

Jenjang pendidikan dasar pada Madrasah Ibtidaiyah merupakan jenjang pendidikan yang melandasi jenjang pendidikan menengah. Madrasah Ibtidaiyah memiliki buku ajar yang digunakan dalam proses pembelajaran. Buku ajar sebagai salah satu komponen penting dalam suatu sistem pembelajaran memiliki posisi yang sangat penting. Keberadaan buku ajar menjadi media untuk mentransfer ilmu kepada peserta didik di madrasah

${ }^{1}$ Mujiran, Paulus, Pernak-pernik Pendidikan, Manifestasi dalam Keluarga, Sekolah, dan Penyadaran Jender, (Jogjakarta: Pustaka Pelajar, 2002), h. 137. 
ibtidaiyah. Oleh karena itu memilih buku ajar yang baik menjadi kepentingan utama dalam proses pembelajaran. Buku ajar yang baik dapat mentransfer ilmu pengetahuan dan keterampilan bagi peserta didik pada ranah kognitif, afektif, dan psikomotorik. Buku ajar dipandang sebagai sarana yang harus secara jelas dapat mengkomunikasikan informasi, konsep, pengetahuan dan mengembangkan kemampuan peserta didik. Buku ajar selain harus mampu menyajikan suatu objek secara runtut bagi keperluan pembelajaran juga harus dapat memberikan sentuhan nilai-nilai afektif dan psikomotorik yang adil dan setara jender. Buku ajar yang baik harus menampilkan peran yang dilakukan perempuan dan laki-laki sesuai dengan status, lingkungan, budaya, agama, dan struktur masyarakatnya baik dalam bentuk ilustrasi gambar maupun bahasa dalam bahan ajar. Namun demikian, pada kenyataannya masih banyak buku ajar belum mampu menunjukan adanya perspektif jender, peran laki-laki dan perempuan masih dibedakan dan ditonjolkan secara jelas melalui gambar maupun tulisan yang bias jender. Apabila buku ajar dengan kondisi yang demikian dibiarkan saja tanpa berani melakukan pemilihan buku ajar, maka diprediksikan dapat membentuk pola pikir yang bias jender yang dapat secara terus menerus membentuk nilai-nilai dan sikap (afektif), dan perilaku siswa di sekolah, di rumah, bahkan di masyarakat. Buku ajar yang melahirkan dominasi peran salah satu jenis kelamin dan memarginalkan jenis kelamin tertentu akan memberikan kontribusi pada pelanggengan konstruksi jender yang kurang menguntungkan pada jenis kelamin tertentu. Oleh karena itu, sosialisasi tentang pengetahuan jender dan ruang lingkupnya dipandang perlu untuk diberikan kepada teknisi kurikulum yang ada pada satuan, jenis, dan jenjang pendidikan. Penyusunan buku ajar, pemilihan buku ajar, dan kemampuan untuk melakukan proses pembelajaran di kelas agar tidak menimbulkan bias jender dapat dilakukan oleh guru. Pemilihan buku ajar MI agar berperspektif jender adalah tindakan tepat agar "kekeliruan" pola pikir kognitif dan bentukan afektifnya tidak telanjur jauh terinternalisasi dalam ranah kognitif dan afektif peserta didik di Madrasah Ibtidaiyah. Buku ajarsebagai salah satu input dalam proses pembelajaran yang merupakan pendekatan implementasi kurikulum yang berlaku. Oleh karena itu, ketika kurikulum suatu negara berubah, maka secara otomatis buku ajar yang digunakan juga akan berubah. Oleh karena itu, perlu dilaku- 
kan tinjauan kurikulum di pendidikan dasar Madrasah Ibtidaiyah. Harapan yang diinginkan agar bahan ajar atau buku-buku ajar yang digunakan di MI tidak menimbulkan bias jender, perlu kiranya diadakan penelitian untuk mengidentifikasi bias jender pada gambar dan teks yang terdapat dalam buku ajar Aqidah Akhlak. Penelitian ini dilakukan agar hasil temuannya dapat digunakan sebagai informasi tentang adanya bias jender pada mata pelajaran Aqidah Akhlak dan merekomendasi kepada beberapa pihak terkait untuk menyusun materi buku ajar yang berkeadilan jender. Dengan demikian ketimpangan atau bias jender yang ada dalam materi ajar Aqidah Akhlak dan mata pelajaran yang lain dapat diminimalisir untuk meretas bias jender yang selama ini terjadi pada materi ajar Aqidah Akhlak. Untuk merealisasikan hal tersebut, maka peneliti memandang perlu dilakukan penelitian ini.

\section{B. Kerangka Konseptual}

Terdapat dua kajian pokok dalam kerangka teoritik tulisan ini, sebagai upaya memberikan landasan dan bangunan teoretik atas fokus bahasan, pertama jender dalam pendidikan dan kedua buku ajar.

\section{Jender dalam Pendidikan}

Pendidikan yang berkeadilan jender telah merambah dunia pendidikan, dari level paling bawah, dasar, menengah, hingga level perguruan tinggi. Pendidikan berkeadilan jender mencakup permasalahan berikut ini:

Pertama, madrasah yang responsif jender adalah madrasah yang memiliki aspek akademis, sosial, lingkungan fisik, maupun lingkungan masyarakat yang memperhatikan kebutuhan, permasalahan, pengalaman aspirasi perempuan dan laki-laki di dalam lingkup pendidikan. ${ }^{2}$

Kedua, menurut Peraturan Menteri Pemberdayaan dan Perlindungan Anak No. 11 Tahun 2010 pada poin menimbang butir (c dan d) bahwa madrasah memiliki peran penting dalam meningkatkan mutu, keadilan dan kesetaraan jender di bidang pendidikan; $d$. bahwa berdasarkan pemetaan situasi dan kondisi madrasah dari aspek pengelolaan, proses pembelajaran, Ayat 2.

2Peraturan Menteri Pemberdayaan dan Perlindungan Anak No. 11 tahun 2010 Pasal 1 
dan partisipasi masyarakat masih ada kesenjangan jender, karenanya perlu pembinaan dan pengembangan agar menjadi satuan pendidikan yang berwawasan kesetaraan jender. ${ }^{3}$

Menurut Peraturan Menteri Pemberdayaan dan Perlindungan Anak No. 11 Tahun 2010 pada Pasal 6 butir a-e bahwa pedoman pelaksanaan pengarusutamaan jender di madrasah sebagaimana dimaksud dalam Pasal 5 memiliki indikator kinerja. Diterapkannya satuan-satuan pendidikan yang berwawasan keadilan dan kesetaraan jender sehingga dapat memberikan dampak yang berlipat ganda terhadap peningkatan keadilan dan kesetaraan jender dalam berbagai bidang pembangunan dan kehidupan masyarakat. Diterapkannya langkah-langkah pengarus-utamaan jender di madrasah untuk meningkatkan kualitas sumberdaya manusia laki-laki dan perempuan.

Perbedaan jender dengan pemilahan sifat, peran dan posisi tidak menjadi masalah/problem sepanjang tidak melahirkan ketidakadilan. Pada kenyataannya perbedaan jender telah memicu ketidakadilan jender, bukan saja pada perempuan namun juga pada laki-laki. Studi jender pada dasarnya bertujuan untuk mengurangi dan menghilangkan ketidakadilan jender. Mewujudkan keadilan sosial hanya dapat diwujudkan dengan mewujudkan keadilan jender. Keadilan jender biasanya merujuk pada aplikasi keadilan sosial dalam hal pemberian kesempatan yang sama antara laki-laki dan perempuan. Dalam hal ini keadilan tidak berarti bahwa laki-laki dan perempuan harus sama dalam segala hal, namun yang dimaksud dengan keadilan jender adalah pemberian kesempatan dan akses tidak tergantung pada perbedaan jenis kelamin.

Keadilan jender adalah antara laki-laki dan perempuan memiliki dan menikmati status yang sama, sama-sama memiliki kesempatan yang sama untuk merealisasikan hak- haknya dan potensi dirinya dalam memberikan kontribusi pada perkembangan politik, ekonomi, sosial dan budaya serta sama-sama dapat menikmati hasil-hasil pembangunan tanpa harus membedakan jenis kelamin.

3Peraturan Menteri Pemberdayaan dan Perlindungan Anak Nomor 11 tahun 2010 tentang Pedoman Pelaksanaan Pengarusutamaan Gender di Madrasah Kementerian Agama Republik Indonesia, Jakarta: Berita Negara RI, 2010. 
Upaya-upaya yang dapat ditempuh untuk mewujudkan keadilan jender antara lain menerima dan memandang secara wajar perbedaan yang ada pada laki-laki dan perempuan, mendiskusikan bagaimana cara merombak struktur masyarakat yang membedakan peran dan relasi antara laki-laki dan perempuan, serta berupaya menyeimbangkannya, meneliti kemampuan dan bakat masing-masing warga negara baik laki-laki maupun perempuan untuk terlibat dalam pembangunan masyarakat, memberikan solusi-solusi dan mempersiapkan masa depannya, memperjuangkan terus menerus hak asasi manusia, dimana di dalamnya termasuk urusanjender, mengupayakan perkembangan dan penegakan demokrasi dan pemerintahan yang baik dalam semua institusi masyarakat dan melibatkan perempuan dalam semua level. Pendidikan merupakan kunci bagi keadilan jender, karena pendidikan merupakan tempat untuk menstranfer norma-norma, pengetahuan dan kemampuan mereka.

\section{Bias Jender dalam Pendidikan}

Bias gender adalah mengunggulkan salah satu jenis kelamin dalam kehidupan sosial atau kebijakan publik. Bias gender dalam pendidikan adalah realitas pendidikan yang mengunggulkan satu jenis kelamin tertentu sehingga menyebabkan ketimpangan gender. ${ }^{4}$ Bentuk kesenjangan jender yang terjadi dalam kehidupan masyarakat terrepresentasi dalam dunia pendidikan. Institusi pendidikan sering dipandang ikut berperan dalam mensosialisasikan dan melestarikan nilai-nilai serta cara pandang yang mendasari munculnya berbagai ketimpangan jender dalam masyarakat. Fenomena kesenjangan jender dalam pendidikan dapat diklasifikasikan dalam beberapa dimensi, diantaranya adalah:

\section{Kurangnya Partisipasi (Under-Participation)}

Angka partisipasi perempuan diseluruh dunia menghadapi problem yang sama. Dibandingkan laki-laki, angka partisipasi perempuan dalam pendidikan formal jauh lebih rendah. Bahkan dinegara dunia ketiga dimana pendidikan dasar belum diwajibkan, jumlah murid perempuan hanya separuh

${ }^{4}$ Hanum Asroah, Sosiologi Pendidikan,cet. I, (Surabaya: Kopertais Press, 2008), h. 56. 
atau sepertiga jumlah murid laki-laki. ${ }^{5}$ Pada tingkat SLTP/ Tsanawiyah dan SMU/Madrasah Aliyah perbedaan angka partisipasi menurut jenis kelamin lebih banyak terjadi pada daerah-daerah yang masih kekurangan fasilitas pendidikan, terutama didaerah-daerah pedesaan dan luar Jawa.

\title{
2. Kurangnya Keterwakilan (Under-Representation)
}

Partisipasi perempuan dalam pendidikan sebagai tenaga pengajar maupun pemimpin juga menunjukkan kecenderungan disparitas progresif. Jumlah guru perempuan pada jenjang pendidikan dasar umumnya sama atau melebihi jumlah guru laki-laki. Namun pada jenjeng pendidikan lanjutan dan pendidikan tinggi jumlah tersebut menunjukan penurunan drastis. Selain itu partisipasi perempuan dalam proses pengambilan keputusan pendidikan sangat rendah karena akses perempuan juga masih dirasakan rendah dalam menempati jabatan-jabatan birokrasi pemegang kebijakan. Proporsi kepala sekolah perempuan secara konsisten masih kecil dibandingkan dengan laki-laki pada setiap jenjang pendidikan. Perempuan pemegang jabatan struktural, dari tingkatan strategis sampai operasional jauh lebih rendah daripada lawan jenisnya. Oleh karena itu banyak kebijakan pendidikan kurang sensitif gender, yang akan berdampak luas terhadap berbagai dimensi bias gender dalam pendidikan.

\section{Perlakuan yang tidak Adil (Unfair Treatment)}

Kegiataan dan proses interaksi dalam kelas seringkali bersifat merugikan murid perempuan. Guru secara tidak sadar cenderung menaruh harapan dan perhatian yang lebih besar kepada murid laki-laki dibanding murid perempuan. Para guru kadangkala cenderung berfikir ke arah "self fulfilling prophecy" terhadap siswa perempuan karena menganggap perempuan tidak perlu memperoleh pendidikan yang tinggi. Secara khusus faktor penyebab bias gender dalam pendidikan antara lain perbedaan angka partisipasi pendidikan pada tingkat SD/Ibtidaiyah sudah mencapai titik optimal yang tidak mungkin diatasi hanya dengan kebijakan pendidikan, pada tingkat SLTP/Tsanawiyah dan SMU/Madrasah Aliyah perbedaan angka partisipasi menurut gender lebih banyak terjadi pada daerah-daerah

\author{
2005), h. 32.
}

${ }^{5}$ Amasari, Pendidikan Berbasis Gender, Laporan Penelitian, (Banjarmasin: IAIN Antasari, 
yang masih kekurangan fasilitas pendidikan, terutama didaerah- daerah pedesaan dan luar Jawa, laki- laki lebih dominan dalam mempengaruhi isi kurikulum sehingga proses pembelajaran cenderung bias laki-laki (male bias). Fenomena ini dapat diamati dari buku-buku pelajaran yang sebagian besar penulisnya adalah laki-laki. Penulis buku laki-laki sangat dominan, isi buku pelajaran yang membahas status perempuan dalam masyarakat akan banyak memberikan pengaruh terhadap kesenjangan gender dalam proses pendidikan. Muatan dari sebagian buku-buku pelajaran (khususnya IPS, PPKN, Pendidikan Jasmani, Bahasa dan Sastra Indonesia, Kesenian dan sejenisnya) yang berhasil diamati cenderung kurang berwawasan gender khususnya berkaitan dengan konsep keluarga atau peran perempuan dalam keluarga yang telah lama dipengaruhi oleh cara berpikir tradisional, bahwa laki- laki adalah pemegang fungsi produksi sedangkan perempuan memegang fungsi reproduksi. Bahasa, merupakan unsur yang sangat penting dalam pendidikan peka jender, lewat pilihan kata, tekanan-tekanan, konstruksi kalimat atau ujaran yang digunakan tertulis maupun lisan. Bahasa tidak terbatas pada bahasa verbal namun juga termasuk bahasa non verbal, bahasa tubuh seperti cara bersalaman, memberi penghormatan, memandang atau mengerling menyiratkan makna yang mengandung muatan jender. ${ }^{6}$

\section{E. Buku Ajar}

Guru dalam meningkatkan kompetensinya memerlukan bantuan berbagai sarana sumber belajar yang dapat membantunya melaksanakan proses pembelajaran dengan baik dan lancar. Salah satu sumber belajar tersebut adalah buku ajar yang menjadi pegangan dalam mengajar di kelas. Melalui acuan buku ajar yang baik, guru akan sangat terbantu dalam mempersiapkan proses pembelajarannya.

Buku ajar merupakan salah satu sarana untuk menunjang proses kegiatan belajar-mengajar. Menurut Bahrul Hayat, dkk dalam Pedoman Sistem Penilaian dikatakan bahwa buku teks adalah buku ajar yang memiliki peranan dalam menentukan keberhasilan pendidikan peserta didik.7 Lebih lanjut dikemukakan bahwa buku ajar merupakan buku untuk tingkatan TK,

${ }^{6}$ Achmad Muthia'in, Bias Gender dalam Pendidikan, (Surakarta: UMS Press, 2001), h. 19.

7Bahrul Hayat, Sistem Penilaian Buku, (Jakarta: Pusat Perbukuan, 2001), h. 42. 
SD, SMP dan sederajat, SMA dan sederajat, SLB, PT/Universitas yang digunakan peserta didik dan atau guru, serta digunakan sebagai salah satu sarana dalam proses belajar-mengajar.

Buku ajar (buku teks) juga dipandang sebagai sarana untuk mengkomunikasikan ilmu pengetahuan. Buku ajar yang digunakan guru dan peserta didik di sekolah harus secara jelas dapat mengkomunikasikan informasi, konsep, pengetahuan, dan mengembangkan kemampuan sedemikian rupa sehingga dapat dipahami dengan baik oleh guru dan peserta didik. Dengan kata lain, buku ajar adalah media bagi penyajian suatu objek secara terurut bagi keperluan mengajar dan belajar, sehingga bermanfaat untuk pengonstruksian suatu situasi belajar secara spesifik.

Buku ajar dapat diartikan sebagai bagian organik dari suatu kurikulum. Oleh karena itu materi yang terkandung dalam buku ajar harus sesuai dengan sistematika rincian bahan pengajaran yang tertera dalam silabus mata pelajaran yang bersangkutan. ${ }^{8}$ Munculnya kebijakan Standar Mutu Buku Pelajaran yang dikeluarkan oleh Pusat Perbukuan Depdiknas, karena ada beberapa alasan dan pertimbangan yang melatarbelakangi, yaitu: 1) Buku pelajaran dipandang memiliki peran penting dan strategis dalam peningkatan mutu pendidikan. 2) Perlunya buku pelajaran yang digunakan di sekolah disusun berdasarkan pedoman yang ditetapkan Pemerintah, meskipun dapat diterbitkan oleh Pemerintah maupun swasta. 3) Berdasarkan UU No. 22 Tahun 1999 dan PP No. 25 Tahun 2000, Pemerintah Pusat memiliki kewenangan menetapkan norma, standar, dan prosedur. Kemudian berdasarkan UU No. 20 Tahun 2003 tentang Sistem Pendidikan Nasional dinyatakan bahwa standar nasional pendidikan digunakan sebagai acuan untuk pengembangan kurikulum, tenaga kependidikan, sarana dan prasarana, pengelolaan, dan pembiayaan. ${ }^{9}$ 4) Salah satu permasalahan peningkatan mutu pendidikan dalam rangka otonomi daerah adalah: terbatasnya SDM perbukuan, terbatasnya informasi perbukuan, belum adanya standardisasi mutu buku, dan belum adanya pengendalian mutu buku (quality control).

8Muhammad Ansyor, dan Nurtain, Pengembangan dan Inovasi Kurikulum, (Jakarta: Depdikbud, 1991), h. 17.

9 Undang-Undang Sisdiknas No.20 tahun 2003, (Jakarta: Sekretariat Negara, 2003). 
Berdasarkan latar belakang itulah, maka Pusat Perbukuan Depdiknas mengeluarkan Kebijakan SMBP sesuai dengan tugasnya sebagai pengendali mutu buku. Hal ini juga sesuai dengan visinya, yaitu tersedianya buku pendidikan yang bermutu, dan misinya, yaitu melakukan standardisasi mutu buku, mengendalikan mutu buku, dan mendorong pertumbuhan dan perkembangan industri perbukuan agar menghasilkan buku yang bermutu.

\section{Standar Mutu Buku Pelajaran}

Buku ajar yang baik adalah buku ajar yang mampu memenuhi kebutuhan yang diinginkan peserta didik sesuai dengan tahap perkembangannya. Oleh karena itu buku ajar harus senantiasa dikontrol mutunya agar benar-benar dapat membantu meningkatkan prestasi belajar peserta didik. Menurut Taya, mutu atau kualitas buku ajar dapat dilihat dari segi fisik, seperti desain grafis, ukuran kertas, ukuran kuarto, dan lain-lain, dan dari segi isi, seperti sejauhmana materi yang ada memenuhi tuntutan kurikulum yang berlaku dan sejauhmana kebenaran dan keutuhan materi yang ada sesuai dengan disiplin ilmunya. ${ }^{10}$ Pendapat lain dikemukakan oleh Gwynn dan Chase yang dikutip oleh Muhammad Ansyor (1991) buku ajar yang dapat digunakan adalah yang memenuhi kriteria sesuai dengan filsafat bangsa, mencakup materi belajar yang cukup luas, memuat pesan dan tingkat kesulitan bahasa yang sesuai dengan tingkat kematangan peserta didik, memuat latihan dan review materi pelajaran yang memadai, dan peduli terhadap perkembangan zaman.

Adapun standar mutu buku pelajaran yang dimaksud oleh Puskur adalah menyangkut syarat, karakteristik, dan kompetensi minimum yang harus dipenuhi oleh suatu buku ajar. Sebagai contoh, bila seseorang memutuskan menggunakan suatu buku ajar, maka ia akan mengacu dan melihat buku tersebut dari berbagai hal, seperti: kebenaran isi, kejelasan penyajian materi, keterurutan penyajian, ilustrasi yang jelas, soal dengan tingkat kesulitan dan konteks yang bervariasi, bahasa yang baik dan komunikatif, dan memunculkan cara berpikir logis.

Standar mutu buku ajar tersebut dapat ditingkatkan dan dimodifikasi di masa mendatang sesuai dengan kondisi dan tuntutan kurikulum yang ber-

10 Paembonan Taya, Penerbitan dan Pengembangan Buku Pelajaran di Indonesia, (Jakarta: Depdikbud, 1990), h. 31. 
laku, perkembangan IPTEK, dan juga tuntutan masyarakat. Adapun standar mutu buku pelajaran yang ditetapkan sebagai pedoman penilaian oleh Puskur meliputi beberapa aspek, yaitu:

\section{Aspek Penyajian}

Standar yang berkaitan dengan aspek penyajian buku ajar meliputi teknik penyajian (keruntutan konsep, kekonsistenan sistematika, keseimbangan antar bab), penyajian pembelajaran (berpusat pada peserta didik, mengembangkan keterampilan proses, memperhatikan aspek keselamatan kerja, variasi penyajian, dan pembelajaran terpadu), dan kelengkapan penyajian (pendahuluan, daftar isi, glosarium, daftar pustaka, ringkasan dan peta konsep, evaluasi, indeks, dan ilustrasi yang mendukung pesan). Pada aspek penyajian butir 24 terdapat deskripsi yang berbunyi ilustrasi yang disajikan relevan dengan pesan yang disampaikan ilustrasi tersebut, tidak bias gender, dan tidak menunjukkan kekerasan. Hal ini menunjukkan bahwa dalam penyajian materi ajar, baik berupa ilustrasi, gambar, maupun kalimat harus memperhatikan keadilan dan kesetaraan gender.

\section{Aspek Bahasa}

Standar yang berkaitan dengan aspek bahasa/keterbacaan yang harus ada: kesesuaian dengan tingkat perkembangan (berpikir, sosial, dan emosional) peserta didik, komunikatif, seperti keterpahaman pesan, ketepatan tata bahasa dan ejaan, kebakuan istilah dan simbol, keutuhan makna, dan keterkaitan antar bab, sub-bab, paragraf, dan kalimat.

\section{Aspek Grafika}

Dalam industri perbukuan, peranan penulis, penerbit, dan percetakan (industri grafika) merupakan mata rantai yang saling terkait dan tidak terpisahkan. Masing-masing komponen memiliki peran besar dalam menghasilkan buku yang baik sebagai produk pemikiran yang profesional. Penulis berperan sebagai penyampai gagasan/informasi/materi pengetahuan, penerbit mengolah naskah hingga menjadi buku layak terbit, dan pada bagian akhir penampilan buku yang diterbitkan harus ditunjang oleh mutu fisik buku yang baik. Mutu fisik buku dihasilkan dari perencanaan buku yang berkaitan dengan aspek grafika, mulai dari desain, reproduksi gambar, cetak hingga penjilidan. Fisik buku dapat ditinjau dari dua aspek, yaitu 
aspek visual yang dapat menunjang keterbacaan materi sehingga penyampaian materi pelajaran lebih mudah diserap dan dipahami, dan aspek teknis yang menyangkut fisik buku yang akan membuat nyaman dan menimbulkan kesenanganjiwa peserta didik dalam menyimak dan menggali pengetahuan yang ada dalam buku, dan daya tahan buku. Berkenaan dengan hal itu, maka dalam standardisasi mutu buku pelajaran, ditambahkan satu aspek, yaitu aspek grafika. Grafika adalah segala cara pengungkapan (pikiran, gagasan, perasaan, pengalaman) dengan huruf, tanda dan/atau gambar, yang diperbanyak dengan mencetak guna disampaikan pada khalayak umum sebagai media massa.

Standar yang berkaitan dengan mutu fisik buku meliputi: bahan buku, ukuran/format buku, desain kulit, desain isi, cetak, penyelesaian dan jilid. Proses pembuatan desain, pola buku, penyusunan huruf, pemilihan dan penerapan tipografi, pembuatan ilustrasi, pemilihan bahan kertas, teknik cetak serta teknik jilid, kesemuanya termasuk komponen grafika yang mengemas materi tulisan menjadi fisik buku pelajaran. Fisik buku memiliki peranan yang sama pentingnya dengan isi atau materi buku. Keduanya memiliki peran tersendiri agar dapat diterima secara optimal oleh pengguna buku pelajaran. Dengan penanganan aspek grafika secara benar, fisik buku pelajaran dapat lebih menarik, dapat menumbuhkan minat membaca, dan pada akhirnya materi yang disajikan lebih mudah diserap. Untuk mengetahui secara objektif buku ajar yang disusun benar-benar membantu peserta didik dalam penguasaan materi, maka harus dilakukan ujicoba penggunaan buku ajar tersebut kepada peserta didik selaku pengguna dan dievaluasi untuk jangka waktu tertentu.

\section{F. Telaah Penelitian yang Relevan}

Raharjo (Ketua Sub Pokja Bahan Ajar Responsif Gender) dari Tim Peneliti LIPI membuktikan bahwa buku- buku pelajaran SD sarat dengan nuansa bias gender lebih dari 50\%, meskipun telah dilakukan perbaikan namun masih ditemukan bias gender dalam buku ajar. ${ }^{11}$ Pemahaman yang keliru tentang gender "dipelihara" dalam buku-buku pelajaran di sekolah. ${ }^{12}$

\footnotetext{
11http://www.suarapembaharuan.com/news/2003/02/11/Kesra/Kes02.htm, diakses 22 Oktober 2013.

12Siti Farikhah, "Bias Gender dalam Pendidikan," Makalah, (tidak diterbitkan), STAIN Salatiga, 2000, h. 3.
} 
Seperti dari hasil penelitian terhadap isi buku pelajaran yang digunakan di sekolah dasar (SD) menunjukkan bahwa ilustrasi di dalam buku pelajaran lebih banyak menonjolkan anak laki-laki daripada anak perempuan. Anak laki-laki yang digambarkan juga lebih beragam dan kreatif perannya dibandingkan anak perempuan. Selain itu anak laki-laki lebih banyak disebut dalam buku-buku dibandingkan anak perempuan (UNICEF, 2007). Hasil penelitian yang dilakukan Logsdon (1985) serta penelitian yang telah dilakukan oleh Astuti, Indarti dan Satriyani (2006) menunjukkan bahwa bukubuku teks yang digunakan di SD, ternyata masih memuat bias gender yaitu memuat pemilahan antara laki-laki dan perempuan. Ayah digambarkan bekerja di sektor publik seperti dikantor, di kebun, disawah dan sebagainya, sedangkan ibu digambarkan bekerja di sektor domestik, seperti didapur, memasak, mencuci, mengasuh adik dan sejenisnya.

Astuti dalam Margono (2002) dalam evaluasi buku pelajaran Bahasa Indonesia dan matematika SD, SLTP dan SMA terlihat bahwa 95\% gambar-gambar dalam buku matematika adalah laki-laki. Selanjutnya dalam buku-buku pelajaran pada umumnya aktivitas permainan anak perempuan dan laki-laki digambarkan dengan pemisahan yang tegas, seperti anak laki-laki bermain mobil-mobilan, sepak bola, berlari-lari dan naik ke pohon, sedangkan anak perempuan bermain boneka atau masak-masakan. Dalam buku-buku pelajaran itu permainan anak laki-laki digambarkan dengan kegiatan fisik aktif dan mobil, sedangkan anak perempuan gambaran fisiknya cenderung lebih pasif. ${ }^{13}$

\section{G. Metodologi Penelitian}

Penelitian ini termasuk penelitian kualitatif, yaitu penelitian yang bertujuan untuk melakukan penilaian terhadap kualitas buku ajar atau materi ajar di tinjau dari perspektif jender dengan mengidenfikasi bias jender dalam kalimat dan gambar di buku ajar yang menjadi sampel. Hasil penelitian ini kemudian digunakan sebagai dasar untuk memperbaiki kekurangan yang terdapat dalam buku ajar tersebut. Populasi dalam penelitian ini adalah buku ajar pada mata pelajaran Aqidah Akhlak kelas 1, 2, 3, 4, 5 dan 6 yang digunakan di Madrasah Ibtidaiyah di Kota Salatiga, Kabupaten Magelang,

${ }^{13}$ Margono, "Evaluasi Buku Pelajaran Bahasa Indonesia dan Matematika SD,SMP dan SMA", Laporan hasil penelitian, (tidak diterbitkan), 2002, h. 1. 
dan Kabupaten Ponorogo. Teknik pengambilan atau pemilihan sampel menggunakan teknik purposive random sampling. Sampel berupa buku ajar mata pelajaran Aqidah Akhlak yang diterbitkan oleh beberapa penerbit yang terbanyak digunakan di Madrasah Ibtidaiyah di tiga kota tersebut.

Variabel dalam penelitian ini adalah kriteria bias jender pada buku ajar yang digunakan di Madrasah Ibtidaiyah, yang terdiri dari dua sub-variabel peran dan stereotipe jender. Peran jender yaitu peran yang dilakukan perempuan dan laki-laki sesuai dengan status, lingkungan, budaya dan struktur masyarakatnya yang dibedakan atas tiga aspek, yaitu peran produktif, peran reproduktif dan peran sosial. Peran reproduktif yaitu semua kegiatan yang menghasilkan barang dan pelayanan untuk konsumsi dan perdagangan peran jender,yakni semua kegiatan yang mereproduksi tenaga kerja manusia, seperti merawat anak, memasak, memberi makan, mencuci, membersihkan, mengasuh dan aktivitas rumah tangga lainnya. Peransosial yaitu semua kegiatan yang diperlukan untuk menjalankan dan mengorganisasikan kehidupan masyarakat, pemerintah, organisasi dan partisipasi dalam kegiatan sosial dan budaya (kerja bakti, gotong royong, pembuatan jalan kampung, perawatan kesehatan, sekolah dan lain-lain).

Stereotipe jender yaitu suatu pelabelan atau bentuk generalisasi perilaku individu-individu dari anggota kelompok tertentu, baik itu menurut suku bangsa, bangsa, dan/atau jenis kelamin dengan pelabelan tersebut yang belum tentu benar. Hal ini dapat ditinjau dari aspek sifat perilaku jender, nilai jender, dan status jender. Sifat perilaku jender merupakan pelabelan tentang perilaku perempuan pada hal-hal yang feminin, sedangkan laki-laki pada hal-hal yang maskulin. Nilai jender merupakan pelabelan warna-warna baju, barang (alat tulis, meja belajar, mainan), profesi sesuai dengan jenis kelamin. Status Jender merupakan pelabelan status laki-laki sebagai pemimpin dan kepala keluarga, sedangkan perempuan sebagai anggota pengikut (partisipan pasif) dalam beragam kegiatan pembangunan.

Penelitian ini menggunakan instrumen berupa lembar identifikasi bias jender yang berisi tentang paparan gambar-gambar dan kalimat-kalimat yang menunjukkan bias jender pada peran jender seperti peran produktif, reproduktif, dan sosial. Terdapat stereotipe jender sperti sifat perilaku jender, nilai jender, dan status jender. Data dikumpulkan satu-persatu dengan mengidentifikasi secara cermat ada tidaknya bias jender dari masing-masing buku yang menjadi sampel pada gambar dan bahasa yang digunakan. Data 
dikategorikan ke dalam masing-masing sub-variabel agar terlihat jelas, pada aspek manakah terjadi bias jender. Teknik analisis data yang digunakan adalah analisis isi, sarana tanda, dan analisis wacana ${ }^{14}$. Analisis isi (Content Analysis) adalah teknik penelitian untuk membuat inferensi-inferensi yang dapat ditiru (replicable), dan sahih data dengan memperhatikan konteksnya. Analisis isi berhubungan dengan komunikasi atau isi komunikasi. Logika dasar dalam komunikasi, bahwa setiap komunikasi selalu berisi pesan dalam sinyal komunikasinya itu, baik berupa verbal maupun nonverbal. Sejauh ini, makna komunikasi menjadi amat dominan dalam setiap peristiwa komunikasi. Analisis pragmatis dilakukan dengan melakukan klasifikasi terhadap tanda menurut sebab akibatnya yang mungkin. Misalnya, berapa kali suatu gambar ditampilkan yang dapat mengakibatkan munculnya sikap tertentu terhadap gambar yang ditampilkan. Teknik analisis ini digunakan untuk menganalisis bahasa tulis berupa gambar dan bahasa yang digunakan pada buku ajar mata pelajaran Aqidah Akhlak di MI.

Analisis isi semantik dilakukan untuk mengklasifikasikan tanda menurut maknanya. Analisis ini terdiri dari tiga jenis yaitu analisis penunjukan (designation), menggambarkan frekuensi seberapa sering objek tertentu (orang, benda, kelompok, atau konsep) dirujuk. Teknik analisis ini digunakan untuk menganalisis bahasa tulis berupa gambar dan bahasa yang digunakan pada buku ajar mata pelajaran Aqidah Akhlak di MI. Analisis penyifatan (attributions) dengan menggambarkan frekuensi seberapa sering karakterisasi dirujuk seperti penyifatan pada peran publik dan domestik yang dimiliki pada jenis kelamin perempuan dan jenis kelamin laki-laki yang ditampilkan dalam gambar dan bahasa. Teknik analisis ini digunakan untuk menganalisis bahasa tulis berupa gambar dan bahasa yang digunakan pada buku ajar mata pelajaran Aqidah Akhlak di MI. Analisis Pernyataan (assertions) menggambarkan frekuensi seberapa sering objek tertentu dikarakteristikkan secara khusus. Analisis ini secara kasar di sebut analisis tematik. Analisis ini menggambarkan pada pelabelan khusus yang dimiliki oleh jenis kelamin perempuan dan laki-laki. Teknik analisis ini digunakan untuk menganalisis bahasa tulis berupa gambar dan bahasa yang digunakan pada buku ajar mata pelajaran Aqidah Akhlak di MI.

${ }^{14} \mathrm{http}: / /$ shindohjourney.wordpress.com.metodelogi-penelitian-komunikasi-analisis isi wacana semiotika framing kebijakan redaksional dan analisis korelasional/Rafian's Journey.Diakses tanggal 22 Oktober 2013. 
Kedua, Analisis Sarana Tanda. Analisis sarana tanda (sign-vechile), dilakukan untuk mengklasifikasi isi pesan melalui sifat psikofisik dari tanda, misalnya berapa kali kata menyapu, mengepel, mencuci, meggendong, bekerja di kantor, dan lain sebagainya muncul. Penggunaan analisis isi lebih banyak ditekankan pada bagaimana simbol-simbol yang ada pada komunikasi itu terbaca dalam interaksi sosial, dan bagaimana simbol-simbol itu terbaca dan dianalisis oleh peneliti. Teknik analisis ini digunakan untuk menganalisis bahasa tulis berupa gambar dan bahasa yang digunakan pada buku ajar mata pelajaran Aqidah Akhlak di MI.

Ketiga, Analisis wacana adalah analisis isi yang lebih bersifat kualitatif dan dapat menjadi salah satu alternatif untuk melengkapi dan menutupi kelemahan dari analisis isi kuantitatif yang selama ini banyak digunakan oleh para peneliti. Jika pada analisis kuantitatif, pertanyaan lebih ditekankan untuk menjawab "apa" (what) dari pesan atau teks komunikasi, pada analisis wacana lebih difokuskan untuk melihat pada "bagaimana" (how), yaitu bagaimana isi teks berita dan juga bagaimana pesan itu disampaikan. Analisis wacanamerupakan suatu kajian yang digunakan secara ilmiah, baik dalam bentuk tulis maupun lisan. Teknik analisis ini digunakan untuk menganalisis bahasa tulis berupa gambar dan bahasa yang digunakan pada buku ajar mata pelajaran Aqidah Akhlak di MI.

\section{H. Hasil Penelitian dan Analisis}

Penelitian ini diawali dengan menentukan buku ajar pada mata pelajaran aqidah akhlak Madrasah Ibtidaiyah kelas 1, 2, 3, 4, 5 dan 6 yang digunakan di Kota Salatiga, diidentifikasi ada tidaknya bias gender secara cermat satu persatu dengan menggunakan pegangan lembar identifikasi yang telah disediakan dan definisi operasional masing-masing aspek dari sub-variabel yang ditentukan. Adapun teknik analisis data yang digunakan dalam penelitian ini adalah: (1) analisis sarana tanda untuk menganalisis gambar yang ada pada buku ajar mata pelajaran Aqidah Akhlak di MI, (2) analisis isi dan analisis wacana, digunakan untuk menganalisis unsur bahasa di dalam buku ajar. Analisis isi merupakan teknik yang berhubungan dengan pesan dalam sinyal komunikasi, sedangkan analisis wacana merupakan analisis isi yang lebih kualitatif. Pada analisis isi cenderung pada apa (what) pesan yang disampaikan, sedangkan pada analisis wacana lebih difokuskan pada bagaimana (how) pesan itu disampaikan. Hasil penelitian 
dan analisis terhadap buku aqidah akhlak kelas 1 sampai dengan kelas 6 adalah sebagai berikut:

\section{Buku Aqidah Akhlak Kelas 1}

Hasil penelitian dan analisis gambar dari buku aqidah Akhlak kelas 1 dalam struktur pelajarannya meliputi:

\section{a. Pelajaran 1}

Pada Pelajaran 1, guru digambarkan laki-laki (ustadz) sementara guru perempuan (ustadzah) tidak ditampilkan sebagai guru. Terdapat jumlah siswa yang berbeda, laki-laki 3 (tiga) orang dan perempuan 4 (empat) orang. Jumlah tidak berimbang antara laki-laki dan perempuan. Terdapat minoritas laki-laki dan dominasi perempuan, hal ini menjadikan bias jender dalam materi ajar di Madrasah Ibtidaiyah (MI).

Gambar bos berjenis kelamin laki-laki gendut dengan situasi di ruang kerjanya dikelilingi uang dan lambang kekayaan. Ruang publik digambarkan menjadi milik laki-laki dan ruang. Hal ini menjadikan bias jender dalam materi ajar di MI.

Pada cerita bermakna (qissah mu'assirah), ada gambar laki-laki sebagai wak haji dan perempuan sebagai siswa dengan penggambaran proporsi secara tidak seimbang. Perempuan digambarkan sebagai obyek dan penggambaran yang kecil. Hal ini menjadikan bias jender dalam materi ajar di Madrasah Ibtidaiyah (MI).

\section{b. Pelajaran 2}

Guru ditampilkan pada jenis kelamin laki-laki dengan jumlah siswa sama masing-masing sebanyak 8 orang. Penggambaran posisi duduk antara laki-laki dan perempuan tidak sama, perempuan semua duduk di kursi belakang dan laki-laki semua duduk di bagian depan. Gambar melukiskan perempuan tidak penting, kurang penting, dan hanya sebagai pelengkap sehingga cukup dilukiskan di bagian belakang. Hal ini menjadikan bias jender dalam materi ajar di MI.

Seorang laki-laki sedang melaksanakan shalat dengan posisi berdiri dan perempuan sedang membaca quran dengan posisi duduk. Posisi berdiri dan duduk menandai jenis kelamin tertentu lebih unggul dibandingkan dengan jenis kelamin yang lainnya. Posisi shalat dapat digambarkan dengan posisi 
yang sedang duduk, dengan demikian tidak menandai keberbedaan tinggi dan rendah antara psosisi perempuan dan laki-laki. Hal ini menjadikan bias jender dalam materi ajar di MI.

Seorang ustadzah sedang mengajarkan bagaimana jadi anak baik, jumlah personal siswa laki-laki dan perempuan tidak berimbang, perempuan berjumlah 6 (enam) orang sementara laki-laki 8 orang. Keberbedaan tersebut menandai peluang dibuat berbeda. Hal ini menjadikan bias jender dalam materi ajar MI.

\section{c. Pelajaran 3}

Abi dan anaknya (laki-laki dan perempuan), digambarkan gambar lakilaki berstatus sebagai bapaknya digambar lebih besar dibandingkan dengan anaknya (perempuan). Untuk menghindari bias jender, dapat dilakukan dengan menggambar dua jenis kelamin yang berbeda dengan usia yang sama/hampir sama.

\section{d. Pelajaran 4}

Seorang laki-laki dan perempuan sedang mencuci baju. Kegiatan sama, tetapi dilukiskan dalam gambar tersebut jenis kelamin laki-laki duduk di kursi pendek, perempuan jongkok. Laki-laki mencuci dengan posisi di atas, sementara perempuan di bawah dengan menggunakan sikat. Penggunaan sikat menandai pekerjaan yang lebih berat dibandingkan dengan pekerjaan mencuci yang dilakukan oleh laki-laki yang tanpa sikat. Perempuan digambarkan sedang menyetrika dan membuang sampah, melukiskan perempuan berada pada ruang domestik.

Gambar beberapa siswa laki-laki dan perempuan yang sedang membersihkan ruang kelas. Jenis kelamin perempuan (3 orang) digambar lebih sedikit dibandingkan denga laki-laki (5 orang).

Gambar laki-laki dan perempuan. Perempuan membawakan tas lakilaki. Gambar laki-laki dibuat lebih besar daripada perempuan. Kalau dalam kisah tersebut menggambarkan hubungan bakti anak terhadap orangtuanya, mengapa tidak digambarkan anak laki-laki yang membawakan tas bapaknya. Hal ini mengarah pada bias jender pada materi ajar MI.

Gambar ayah dan ibu dengan dua anak, masing-masing laki-laki dan perempuan. Sosok ayah digambar sedang berbicara kepada istri dan anak- 
anaknya pada tempat duduk yang terpisah dengan istri dan anak-anaknya. Posisi tempat duduk ibu dengan anak-anaknya melukiskan anak-anak ada di bawah pengawasan dan tanggung jawab perempuan. Dengan demikian. pemenuhan kebutuhan anak-anaknya menjadi beban perempuan (ibunya). Hal ini menandai adanya bias jender dalam materi ajar MI.

Gambar cerita bermakna (qissah muassirah) menggambarkan orang tua (ayah dan Ibu serta anaknya berangkat ke sekolah. Gambar ayah dengan berpakaian formal dan tas kantor serta berkaca mata, sedangkan ibunya berpakaian muslim non formal. Gambar anak laki-laki digambar lebih besar daripada anak perempuan. Posisi anak perempuan (Anida) di belakang anak laki-laki (Farid) dan digambar lebih kecil daripada laki-laki. Pakaian formal siap bekerja menggambarkan laki-laki ada di sektor publik, sementara perempuan dengan pakaian non formal berada pada sektor domestik. Gambar laki-laki yang mendahului perempuan dan lebih kecil menandai adanya superior atas inferior jenis kelamin tertentu atas jenis kelamin yang lainnya. Hal ini menjadikan materi ajar MI terdapat bias jender.

Gambar Farid dan Anida sedang bercakap dengan teman lainnya. Gambar perempuan (4) lebih banyak dari jenis kelamin lainnya (3). Hal ini menggambarkan perempuan hanya suka untuk berbicara pada forum-forum yang tidak penting (di luar kelas). Hal ini menjadikan materi ajar MI terdapat bias jender.

Gambar Farid dan Anida bermain bersama. Aktivitas Farid bermain dengan aneka mainannya, sementara Anida tidak memegang mainan yang berada di keranjang, Anida hanya melihat. Terdapat dominasi peran yang digambarkan pada Farid, sementara Anida menjadi minoritas yang tidak diberi peluang untuk bermain dengan menggunakan mainan yang sudah disediakan dalam keranjang. Hal ini melukiskan bias jender dalam materi ajar MI.

\section{e. Pelajaran 5}

Gambar ustadzah sedang mengajarkan tentang hidup bersih. Jumlah siswa berjenis kelamin laki-laki dan perempuan berimbang (masing-masing 4 orang), hanya saja posisi laki-laki secara berderet berjumlah tiga orang di depan, sementara perempuan satu orang sejajar dengan laki-laki, perempuan yang lain ada di belakang. Posisi demikian menunjukkan posisi tidak setara antara jenis kelamin tertentu dengan jenis kelamin lainnya. Gambar laki-laki satu orang di belakang juga menggambarkan adanya 
diskriminasi antara 3 orang laki-laki dengan satu orang laki-laki. Demikian juga dengan posisi perempuan yang menunjukkan satu orang diposisikan lebih ke depan daripada perempuan lainnya.

Gambar penjual dan pembeli makanan berulang dilekatkan pada gambar perempuan, hal ini menandai perempuan dikonstuksi dekat dengan persoalan domestik, perempuan hanya bisa melaksanakan fungsi publik pada hal-hal kecil sebagai penjual makanan kecil dan kotor. Hal ini dapat menghadirkan bias jender bagi perempuan pada materi ajar MI.

Gambar penjual makanan baik kondisi bersih ataupun kotor ditampilkan hanya pada jenis kelamin perempuan. Hal ini melukiskan perempuan hanya dapat bekerja pada sektor publik yang sederhana sebagai penjual makanan kecil dan sedikit. Hal ini Hal ini dapat menghadirkan bias jender bagi perempuan dan laki-laki.

Gambar dua orang laki-laki sedang berada di hutan, tidak diikuti dengan jenis kelamin yang lain. Hal ini memberikan gambaran bahwa lakilaki saja yang memiliki kekuatan dan keberanian berada di hutan. Dengan demikian gambar ini menunjukkan adanya bias jender.

Teks dan bahasa yang disajikan dalam buku pelajaran anak menurut kaidah analisisnya meliputi analisis bahasa dan teks pada pelajaran 4, dan 5 sebagai berikut:

\section{f. Pelajaran 4}

Nikmah anak yang baik, setiap ayah pulang dari kantor Nikmah selalu menyambut dengan senyum. Nikmah menyalami dan membawakan tas ayah. Melihat ayah tampak lelah, Nikmah membuatkan secangkir teh untuk ayah. Perilaku Nikmah untuk membawakan tas dan membuatkan minuman bisa juga dilakukan oleh laki-laki, tetapi mengapa hal itu tidak digambarkan dalam kalimat tersebut. Gambar ini melukiskan perempuan sebagai pelayan laki-laki. Hal ini menandai adanya bias jender dalam materi ajar MI.

Ayah Nikmah bernama Pak Hadi. Pak Hadi (tidak disebut bu Hadi atau nama asli dari istrinya) merasa bahagia memiliki anak yang baik seperti Nikmah dan Andi. Tidak disebutnya nama bu Hadi dalam teks memberikan makna tersirat seakan-akan Nikmah dan Andi hanya miliki Pak Hadi. Pak Hadi tidak pernah memarahi Nikmah dan Andi, berbicara dengan 
lemah lembut penuh kasih sayang, tidak pernah berbicara keras apalagi membentak-bentak. Tidak disebutnya Ibu Hadi dalam teks tersebut hal ini memberikan makna tersirat Ibu Hadi memarahi Nikmah dan Andi, berbicara keras dan membentak-bentak dan tidak menyayangi mereka. Hal ini menandai adanya bias jender dalam materi ajar MI.

Irfan mempunyai banyak teman, salah satunya bernama Ihsan. . irfan anak orang kaya, sebaliknya ihsan anak orang miskin. Jenis kelamin perempuan tidak disebutkan dalam contoh kalimat sabagai bagian dari tokoh utama dalam cerita atau sebagai obyek dalam cerita. Jenis kelamin laki-laki sering digunakan sebagai tokoh utama maupun dalam tokoh pendamping/pelengkap. Hal ini menandai adanya superioritas jenis kelamin tertentu atas jenis kelamin yang lainnya.

\section{g. Pelajaran 5}

Nabila sedang sakit, sepulang sekolah Nabila jajan di pinggir jalan. Rumah Nabila besar dan megah, sayang rumahnya kelihatan kotor. Penggambaran hal-hal yang negatif dilekatkan pada jenis kelamin perempuan. Hal ini menimbulkan bias jender dalam teks kalimat tersebut.

\section{Buku Aqidah Akhlak Kelas 2}

Hasil penelitian dan analisis gambar yang disajikan pada buku pelajaran Aqidah Akhlak kelas 2 memuat:

\section{a. Pelajaran 1}

Penokohan gambar Andi yang berjenis kelamin laki-laki sebagai seorang anak yang cerdas berakhlak mulia dan memiliki kemauan yang keras untuk dapat mengerdarai sepeda, sebenarnya dapat juga diilustrasikan dengan penokohan Ani atau siapa pun itu yang berjenis kelamin perempuan. Penokohan gambar Ibu Andi yang sedang mengajari dan menjaga Andi di saat belajar mengendarai sepeda, akan sangat memperkuat stereotipe bahwa perempuan itu diposisikan sebagai seorang ibu yang bertugas menjaga anak dan peran- peran domestik lainnya. Sebenarnya peran sebagai anak tersebut dapat juga di ilustrasikan oleh anak perempuan dan peran orang tua dapat juga diilustrasikan oleh seorang bapak yang sedang menjaga dan mengajari anaknya naik sepeda. Namun hal itu tidak dilakukan dalam buku ajar ini. 


\section{b. Pelajaran 4}

Ali diilustrasikan sebagai seorang anak laki-laki yang memiliki adab berpakaian yang baik sehingga dapat dijadikan teladan dalam beradab. Dalam pelajaran akhlak terpuji sebenarnya ilustrasi penokohannya dapat diwakilkan pada jenis kelamin laki- laki dan perempuan. Dengan dimunculkannya ilustrasi gambar laki-laki akan semakin memperkuat bahwa diskriminasi terhadap perempuan masih ada. Akan lebih adil jender jika ilustrasi gambarnya diwakilkan pada laki-laki dan perempuan. Dalam buku ajar ini kebanyakan penokohan dan ilustrasi didominasi oleh laki-laki.

Analisis teks menggunakan cerita Ahmad dan bapaknya sama-sama senang merawat ladang. Merawat ladang dan alam adalah tanggung jawab manusia. Dalam kalimat ini tugas merawat ladang identik tugas di sektor publik diilustrasikan dengan tanggung jawab bagi jenis kelamin laki-laki saja yaitu oleh tokoh Ahmad dan Bapaknya. Seharusnya peran tersebut dapat juga dilakukan oleh jenis kelamin perempuan, namun penokohan dalam buku ajar ini tidak dilakukan dan didominasi oleh jenis kelamin laki-laki dalam konteks ini akan semakin menguatkan diskriminasi peran dan stereotipe bagi perempuan.

Analisis atas Anton adalah anak yang rajin shalat. Penokohan Anton yang berjenis kelamin laki-laki sebagai anak yang rajin shalat, sebagai anak yang sholeh dan berbakti kepada orang tuannya jelas sangat diskriminatif terhadap perempuan, karena penokohan tersebut juga dapat diwakilkan kepada jenis kelamin perempuan. Seharusnya dan alangkah baikknya jika diwakilkan kepada baik laki-laki dan perempuan. Namun penokohan dalam buku ajar ini tidak dilakukan dan didominasi oleh jenis kelamin laki-laki.

Analisis ayahnya, Pak Ahmad bekerja sebagai guru bantu, ibunya, Sholeha sebagai ibu rumah tangga. Dalam penokohan tersebut sangat jelas diskriminatifnya bahwa laki-laki dalam hal ini diperankan oleh Pak Ahmad bekerja sebagai guru (diposisikan bekerja di sektor publik) dan perempuan dalam hal ini diperankan oleh ibu Sholeha sebagai ibu rumah tangga (diposisikan bekerja di sektor domestik). Dalam masyarakat kita bekerja di sektor domestik merupakan pekerjaan yang dihargai karena bersifat produktif dan hal ini mendapat pandangan yang lebih tinggi ditengahtengah masyarakat. Semestara perempuan selalu diposisikan dengan penokohan bekerja di sektor domestik yang dianggap tidak produktif. 
Sebenarnya bisa saja dalam konteks tersebut ibu sholehah di tokohkan sebagai seorang guru juga atau bekerja di sektor publik lainnya. Namun dalam buku ajar ini hal tersebut tidak dilakukan.

Analisis pada bahasa/teks, setiap hari Aisyah sebelum berangkat sekolah selalu bersih-bersih rumah membantu orang tuanya. Dalam penokohan tersebut sangat stereotipe yaitu memposisikan perempuan (dalam hal ini ditokohkan oleh Aisyah) sebagai pribadi yang lemah dan bertanggung jawab untuk membantu pekerjaan rumah yang sifatnya domestik. Seharusnya peran tersebut juga dapat dilakukan oleh anak laki-laki (jenis kelamin laki-laki) agar tidak semakin mempertegas stereotipe terhadap perempuan dan laki-laki.

\section{Buku Aqidah Akhlak Kelas 3}

\section{a. Pelajaran 1}

Pada gambar halaman 4 penokohan gambar laki-laki yang panik melihat kebakaran semakin menguatkan bahwa jenis kelamin laki-laki dominan di sektor publik, karena penanggulangan bencana termasuk kebakaran merupakan aktivitas di sektor publik yang sudah seharusnya menjadi tanggung jawab baik perempuan dan laki-laki.

\section{b. Pelajaran 2}

Pada gambar halaman 13 penokohan sebagai anak yang rajin belajar pada jenis kelamin laki-laki semakin menguatkan diskriminasi terhadap perempuan, dimata sebagian besar masyarakat anak laki-laki dipandang lebih berhak untuk dapat menikmati jenjang pendidikan yang lebih tinggi dibandingkan anak perempuan. Sebenarnya penokohan ini dapat saja digambarkan oleh jenis kelamin perempuan, namun dalam buku ini tidak dilakukan.

Pada gambar halaman 14 penokohan sekelompok anak laki-laki dan perempuan yang sedang memberikan bantuan disebuah panti asuhan, aktivitas ini merupakan aktivitas sosial namun penggambaran jumlah anak laki-laki begitu dominan yaitu empat anak laki-laki dan tiga anak perempuan. Dari sisi jumlah gambar jelas tidak ada keseimbangan gender apalagi salah satu gambar tokoh perempuannya masih kecil. Penokohan 
seperti ini seakan mengesankan bahwa peran jenis kelamin laki-laki diranah publik begitu dominan.

Pada gambar halaman 23 penokohan seorang dengan jenis kelamin yang mabuk minuman keras. Jelas sekali bahwa stereotipe dimasyarakat tentang perbuatan tercela tersebut identik dengan jenis kelamin laki-laki, hal ini tidak adil bagi jenis kelamin laki-laki, padahal ada sebagaian jenis kelamin perempuan yang melakukan perbuatan tercela tersebut.

Pada gambar halaman 29 penokohan dalam suasana belajar di ruangan kelas, didominasi oleh jenis kelamin laki-laki yaitu dua orang anak laki-laki dan satu anak perempuan. Dua orang anak laki-laki tersebut digambar lebih besar dan duduknya dibangku depan, sedangkan murid perempuannya digambar lebih kecil dan duduk dibangku belakang. Ilustrasi gambar ini seakan memberikan penegasan bahwa jenis laki-laki lebih berhak untuk sekolah dibandingkan anak perempuan. Sebaiknya penggambaran suasana diruang kelas dibuat adil gender.

Pada gambar halaman 30 penokohan seorang guru berjenis kelamin laki-laki dan seorang murid berjenis kelamin laki-laki sedang saling memberikan salam, semakin mempertegas diskriminasi dan stereotipe terhadap perempuan bahwa laki-laki lebih berhak untuk sekolah dan laki-laki juga lebih dominan di sektor publik. Akan lebih baik lagi jika salah satu peran dalam gambar dihalaman 30 ini berjenis kelamin perempuan.

Pada gambar halaman 31 penokohan dua orang murid laki-laki sedang berbagi kue di depan rangan kelas, dan seorang murid perempuan yang sedang belajar sendiri. Ilustrasi pada gambar tersebut semakin menguatkan diskriminasi dan stereotipe bahwa yang berhak menuntut ilmu adalah lakilaki sedangkan perempuan tidak sepenuhnya berhak. Hal ini dikuatkan dengan ilustrasi gambar jumlah murid laki-laki yang lebih banyak dan digambarkan lebih besar dari dari murid perempuan.

Pada gambar halaman 33 penokohan dalam gambar dua anak laki-laki yaitu Ardi dan Ahmad, Ardi digambarkan sebagai seorang anak yang memiliki sikap suka menolong, sedangkan Ahmad seorang anak yang terjatuh dari naik sepeda. Peran ini sebenarnya netral jender dan dapat ditokohkan dengan gambar anak perempuan, namun kenyataannya kebanyakan penokohan karakter di perankan oleh jenis kelamin laki-laki.

Pada gambar halaman 34 Penokohan dalam gambar aktivitas kegiatan penyerahan sumbangan, dimana Pak Hadi menyerahkan sumbangan 
kepada sebuah madrasah ibtidaiyah negeri. Sedangkan sumbangan diterima oleh kepala sekolah (berjenis kelamin laki-laki). Dalam gambar tersebut juga terlihat dua murid laki-laki dan satu murid perempuan. Bias jender sangat terekam dalam gambar ini tokoh pengusaha sukses dan tokoh kepalah sekolah digambarkan pada jenis kelamin laki-laki. Hal ini semakin memperkuat diskriminasi terhadap perempuan. Peran-peran tersebut sebenarnya dapat digambarkan dengan tokoh berjenis kelamin perempuan, namun hal ini tidak dilakukan oleh pengarang dalam buku ini. Pada gambar halaman 34 penokohan seorang pengusaha yang sukses (Pak Hadi) berjenis kelamin laki-laki. Jelas sangat stereotipe, peran pengusahan yang sukses juga sebenarnya dapat digambarkan berjenis kelamin perempuan, namun hal ini tidak dilakukan di buku ini.

\section{c. Pelajaran 6}

Pada gambar halaman 48 penokohan dalam gambar seorang anak lakilaki yang sedang bermain mobil-mobilan, jelas sangat stereotipe. Dan selalu mengidentikan bahwa mainan mobil-mobilan dengan jenis kelamin lakilaki. Padahal mainan mobil-mobilan adalah netral genjer dan anak perempuanpun juga tidak masalah bermain mobil- mobilan. Pada gambar halaman 49 penokohan seorang ibu yang sedang memarahi anaknya, jelas sangat stereotipe. Jenis kelamin perempuan diidentikan dengan sifat emosional dan kurang rasional. Padahal sifat marah atau emosi dapat dilakukan oleh jenis kelamin apa saja. Gambar ini memperkuat anggapan tersebut.

Pada gambar halaman 50 penokohan seorang anak laki-laki yang kikir tidak mau berbagi dengan adik laki-lakinya, juga merupakan stereotipe terhadap laki-laki yang didentik dengan sifat tercela tersebut. Pada gambar halaman 51 penokohan seorang anak laki-laki yang boros menghamburhamburkan uangnya untuk membeli mainan (mobil-mobilan), gambar ini mengilustrasikan bahwa sifat tercela ini diidentikan dengan jenis kelamin laki-laki padahal jenis kelamin perempuan juga ada yang memiliki sifat tercela ini. Pada gambar halaman 52 penokohan seorang anak laki-laki yang malas belajar sehingga menjadi tidak naik kelas. , juga merupakan stereotipe terhadapjenis kelamin laki-laki yang diidentikan dengan sifat malas. Pada gambar halaman 52 penokohan seorang bos (manajer) yang memarahi karyawannya, semua tokoh ini diperankan oleh jenis kelamin laki-laki. Bos (manajer) menunjukan sebuah jabatan dalam sektor publik dan karyawan 
juga merupakan profesi di sektor publik, semua diidentikan dengan jenis kelamin laki-laki. Padahal bisa juga penokohan tersebut kedalam jenis kelamin perempuan. Gambar ini memberikan penegasan bahwa yang berhak bekerja dan berkarya di sektor publik adalah jenis kelamin laki-laki bukan perempuan.

Hasil penelitian dan analisis teks buku pelajaran aqidah akhlak kelas 3 ditinjau dari bahasa/teks dalam redaksi Pak Hadi adalah seorang pedagang yang kaya dan dermawan di kampungnya. Dalam kalimat tersebut jelas ditokohkan bahwa profesi pedagang dengan jenis kelamin laki-laki. Pedagang adalah profesi di sektor publik dan merupakan kegiatan yang sifatnya produktif. Kalimat ini terdapat bias jender karena profesi pedagang selalu diidentikan dengan jenis kelamin laki-laki. Padahal jenis kelamin perempuan juga bisa diilustrasikan sebagai pedagang.

\section{Buku Aqidah Akhlak Kelas 4}

Hasil Penelitian Dan Analisis teks buku ajar kelas 4 mengenai bahasa dan teks aqidah akhlak kelas 4 sebagai berikut:

\section{a. Pelajaran 1}

Pada gambar halaman 2 penokohan dalam aktivitas melayat semua diilustrasikan dengan jenis kelamin laki-laki. Hal ini semakin mempertajam pelabelan pembagian peran sosial yang timpang jender. Kegiatan sosial kemasyarakatan seperti melayat seharusnya dapat diilustrasikan pada jenis kelamin perempuan sehingga netral jender. Namun hal ini tidak dilakukan pada buku ajar ini. Pada gambar halaman 4 penokohan dalam aktivitas melayat semua diilustrasikan dengan jenis kelamin laki-laki. Hal ini semakin mempertajam pelabelan pembagian peran sosial yang timpang jender. Kegiatan sosial kemasyarakatan seperti melayat seharusnya dapat diilustrasikan pada jenis kelamin perempuan sehingga netral jender. Namun hal ini tidak dilakukan pada buku ajar ini.

\section{b. Pelajaran 2}

Pada gambar halaman 10 penokohan dalam gambar suasana belajar diruang kelas sebagian besar murid berjenis kelamin laki-laki yaitu enam orang sedangkan murid berjenis kelamin perempuan hanya dua orang. Dari segi kuantitas sangat timpang jender, sehingga gambar ini seakan meng- 
ilustrasikan bahwa yang lebih berhak mengeyam pendidikan du bangku kuliah adalah anak laki-laki. Pada gambar halaman 12 penokohan dalam jenis pekerjaan tukang bangunan dengan jenis kelamin laki-laki sangat bias jender dan semakin mempertegas strerotipe bahwa jenis kelamin laki-laki identik dengan pekeraan tukang bangunan, dan bekerja di sektor publik yang produktif. Laki-laki sebagai satu-satunya pencari nafkah bagi keluarganya.

\section{c. Pelajaran 4}

Pada gambar halaman 15 penokohan seorang ibu rumah tangga dan seorang anak laki-laki (Fikri) yang akan berangkat sekolah, menegaskan bahwa posisi perempuan adalah sebagai ibu rumah tangga yang berkegiatan didalam rumah, sedangkan tokoh anak sekolah berjenis kelamin laki-laki juga bias jender karena semakin memperkuat pelabelan bahwa jenis kelamin laki-laki lebih berhak untuk bersekolah. Sebaiknya tokoh menghindari gambar penokohan yang bias jender tersebut.

\section{d. Pelajaran 5}

Pada gambar halaman 34 penokohan Masyitoh (jenis kelamin perempuan) sebagai budak sangat menimbulkan bias jender karena semakin mengokohkan pelabelan terhadap perempuan sebagai pelayan, dan hal ini seakan-akan diperkuat dari sisi sejarah bahwa memang perempuan diposisikan sebagai pelayan. Pada gambar halaman 36 penokohan dalam gambar cerita penghukuman keluarga Masyitoh (semuanya berjenis kelamin perempuan) sedangkan masyarakat yang melihat proses tersebut digambarkan dengan jenis kelamin laki-laki, sebuah ketimpangan dan ilustrasi yang sangat ironi bahwa melalui gambar tersebut seakan disimpulkan bahwa perempuan sebagai mahkluk yang lemah tak berdaya.

\section{e. Pelajaran 6}

Pada hari libur, Abdullah dan Ahmad berkunjung kerumah Ali, mereka berpakaian rapi menutup aurat. Semua penokohan berjenis kelamin laki-laki, kegiatan yang dilakukan oleh para tokoh tersebut adalah berkunjung ke rumah teman. Aktivitas tersebut merupakan aktivitas di luar rumah. Sehingga dapat diintrepretasikan bahwa kegiatan di luar rumah didominasi oleh jenis kelamin laki-laki, seharusnya penokohan dapat diberikan kepada jenis kelamin perempuan juga. 
$\mathrm{Bu}$ Nurul keluar lagi sambil membawa nampan berisi kue dan teh kemudian beliau meletakkannya di meja. Dalam kalimat tersebut jelas kalau steretipe peran sebagai pelayan melekat pada perempuan. Perempuan yang melayani suami, anak dan bahkan tamu dan bertugas untuk membawakan minuman dan makanan kecil untuk tamu.

"Silahkan duduk Ali, sebentar ya bibi ke dapur"

Kutipan kalimat tersebut seolah- olah memberikan gambaran bahwa posisi perempuan adalah didapur.

Abdullah, Ali dan Budi kemudian menuju halaman rumah, mereka bermain loncat tali, mereka bermain dengan riang. Kalimat tersebut menggambarkan bahwa kegiatan diluar rumah seperti bermain ( bermain lompat tali) yang sifatnya bersenang- senang di perankan oleh jenis kelamin laki-laki (Abdullah, Ali dan Budi), sehingga dapat memberikan kesan atau intreprestasi bahwa kegiatan diluar rumah di dominasi oleh jenis kelamin laki-laki.

\section{Buku Aqidah Akhlak Kelas 5}

Hasil penelitian dan analisis gambar buku ajar aqidah dan akhlak kelas 5, ditinjau dari bahasa dan teksnya adalah sebagai berikut:

\section{a. Pelajaran 2}

Penokohan sang juara pada jenis kelamin laki-laki sangat diskriminatif dan menempatkan perempuan pada posisi subordinat. Selama ini karakter pintar, sangat identik dengan jenis kelamin laki-laki sehingga penokohan ini bias jender dalam pendidikan.

Penokohan Anak laki-laki yang giat belajar dan menjadi juara di kelasnya juga bias jender. Jika dianalisis kebanyakan penokohan karakter murid yang sedang belajar, juara diidentikan dengan jenis kelamin laki-laki yang berarti memposisikan perempuan sebagai subordinat yaitu menempatkan perempuan pada posisi yang tidak penting dan dibawah standar lakilaki.

Penokohan seorang pedagang (laki-laki) sedang membuka tokonya untuk memulai berjualan. Dalam masyarakat peran jender jenis laki-laki adalah sebagai pencari nafkah utama dan sedangkan jenis kelamin per- 
empuan sekedar membantu mencari nafkah, sehingga timbul marginalisasi terhadap perempuan. Penokohan dalam gambar tersebut jelas menguatkan posisi marginalitas perempuan sebagai bukan pencari nafkah keluarga.

Penokohan pada gambar Keluarga yang bahagia jelas terlihat dalam keluarga tersebut terdiri dari seorang nenek, seorang kakek, seorang ayah, seorang anak laki-laki dan seorang ibu yang sedang membawa nampan berisi minuman. Disaat semua anggota keluarga digambarkan sedang bercengkrama duduk, maka seorang ibu sibuk membawakan minuman bagi semua anggota keluarga, karena dalam masyarakat perempuan diposisikan dalam posisi subordinat dan diposisikan sebagai pelayan bagi keluarganya. Seharusnya seluruh tokoh dalam gambar tersebut diposisikan sama.

Penokohan Seorang insyinyur sedang bekerja di proyek. Dalam masyarakat peran jender jenis laki-laki adalah sebagai pencari nafkah utama dan sedangkan jenis kelamin perempuan sekedar membantu mencari nafkah, sehingga timbul marginalisasi terhadap perempuan. Penokohan dalam gambar tersebut jelas menguatkan posisi marginalitas perempuan sebagai bukan pencari nafkah keluarga.

\section{b. Pelajaran 4}

Penokohan dalam gambar suasana belajar di Madrasah. Murid-murid perempuan di gambarkan duduk dibangku belakang sedangkan murid lakilaki dibangku depan. Posisi ini jelas menegaskan marginalisasi terhadap perempuan. Seharusnya gambar dibuat netral jender.

Penokohan Aktivitas seorang muslim, digambarkan semua tokoh berjenis kelamin laki-laki mulai dari aktivitas belajar, beribadah dimasjid hingga menjadi juara di kelas. Sangat jelas bahwa gambar tersebut sangat tidak adil jender peran sosial dan publik selalu diidentikan dengan laki-laki. Posisi perempuan seolah-olah diabaikan sehingga tidak dijadikan tokoh pada peran-peran tersebut.

Analisis teks buku pelajaran aqidah akhlak kelas 5 pada aspek bahasa/ teksnya bahwa Dadu adalah anak yang malas, dia sering tidak masuk sekolah, dia sering berbohong kepada ayah ibunya. Penokohan anak yang malas, sering bolos dan berbohong merupakan karakter yang umumnya dilekatkan pada jenis kelamin laki-laki dalam hal ini juga terjadi stereotype pada laki-laki. Seharusnya tidak boleh demikian. 


\section{Buku Aqidah Akhlak Kelas 6}

Gambar dan Teks buku pelajaran aqidaah akhlak kelas 6 dilihat dari penggunaan bahada dan teksnya menjelaskan bahwa posisi perempuan di ranah publik memang sudah ada, namun demikian masih mendapatkan posisi yang dimarginalkan/terpinggirkan. Hal ini dapat dilihat pada beberapa gambar pada materi ajar Aqidah Akhlak di antaranya perempuan masih digambarkan pada gambar yang kecil dibandingkan dengan gambar jenis kelamin yang lain, diletakkan pada posisi di belakang, masih mendapatkan peran yang kurang signifikan bahkan mendiskreditkan perempuan antara lain beberapa sikap negatif yang yang ada dilekatkan pada jenis kelamin perempuan. Perempuan mendapatkan perlakuan yang kurang baik dari laki-laki sperti mendapatkan perlakuan kasar di depan anak-anaknya.

Bahasa yang digunakan pada buku ajar Mata pelajaran Aqidah Akhlak menunjukkan beberapa pelabelan pada jenis kelamin perempuan dengan sifat, dan perilaku negatif. Contoh kalimat Karena gengsi, Isma tidak mau meminta maaf kepada Rani dan Farida berbuat salah kepada Karima. Pak Amir bertetangga dengan Pak Diyo. Rumah Pak Amir di belakang rumah Pak Diyo. Saluran pembuangan air dari rumah Pak Amir dialirkan melewati saluran air Pak Diyo. Istri Pak Diyo suka memfitnah, menyebarkan berita bahwa Pak Amir dan keluarganya selalu membuang kotoran di saluran airnya, padahal Pak Amir dan keluarganya tidak pernah melakukannya. Ketika Istri Pak Diyo sakit dan butuh pertolongan, tidak ada tetangga yang mau menengoknya karena ia suka menceritakan keburukan orang lain. Tetapi Pak Amir dan keluarganya mau mengantarkannya dan menengoknya di rumah sakit. Sedangkan pelabelan pada jenis kelamin laki-laki justru sebaliknya, meskipun pada awal kata yang digunakan adalah sifat dan sikap serta perilaku negatif, tetapi pada kalimat berikutnya dilekatkan sifat, sikap, dan perilaku positif. Ahmad adalah anak seorang petani miskin yang tidak pernah rendah diri di hadapan temantamannya. Ahmad tidak pernah mengeluh dan tidak pernah minta balas kasihan dari orang lain. Rasyid tidak pernah menghina fisik pembantunya. Pak Hamid dikenal sebagai pribadi yang tidak pernah menaruh dendam sedikit pun kepada orang yang menyakiti hatinya. Pak Rasyid merupakan orang bijaksana dalam mengambil keputusan dan bertindak serta atidak tergesa-gesa dalam perilakunya. 
Penggunaan bahasa yang dilekatkan pada laki-laki dengan kalimat yang aman bukan menimbulkan celaka. Saat mendaki ke puncak gunung, Rizal dan teman-temannya memilih jalan yang tidak berbahaya. Nida suka sekali dengan kupu-kupu. Setiap hari dia menangkap kupu-kupu dan dimasukkan ke dalam toples. Kupu-kupu itu banyak yang mati karena tidak dapat bebas bernafas, Bagaiman perbuatan Nida? Perempuan sebagai obyek perilaku kasar yang dimiliki oleh laki-laki, hal ini dapat dilihat pada kalimat Pak gito adalah orang yang suka mabuk-mabukan dan berjudi. Penghasilan dai bekerja habis di meja judi. Jika uangnya habis, di rumah ia sering marah kepada istrinya dan anaknya. Pak Gito memukul istrinya ketika mabuk. Profesi yang dilekatkan pada jenis kelamin laki-laki pada profesi yang baik, biasanya profesi yang dilekatkan pada perempuan pada ranah publik kurang menguntungkan dan bersifat sepele.

\section{Kesimpulan}

Hasil identifikasi bias gender yang ada di dalam buku ajar, baik terhadap gambar maupun deskripsi kalimat yang kemudian berdasarkan kriteria bias gender dalam penelitian ini yang terdiri dari dua sub-variabel, yaitu peran gender yang terdiri dari aspek peran produktif (PP), peran reproduktif (PR), dan peran sosial (PS), dan stereotipe gender yang terdiri dari aspek sifat perilaku gender (PG), nilai gender (NG), dan status gender (SG).

Hasil penelitian terhadap gambar pada materi ajar Aqidah Akhlak mulai dari kelas 1 sampai dengan kelas 6 , sebagian besar perempuan masih digambarkan pada gambar yang kecil dibandingkan dengan gambar jenis kelamin yang lain, diletakkan pada posisi dibelakang, masih mendapatkan peran yang kurang signifikan bahkan mendiskriditkan perempuan antara lain beberapa sikap negatif yang dilekatkan pada jenis kelamin perempuan. Pelabelan atau steriotipe terhadap perempuan bahwa perempuan itu makhluk yang lemah, marginalisasi terhadap perempuan sehingga banyak digambarkan bahwa perempuan hanya bertindak sebagai pelayan keluarga, istri yang hanya melayani suami dan anak-anaknya, subordinasi terhadap hak perempuan untuk menjadi anak yang pintar seperti juara kelas, sekolah, mencari nafkah masih jelas terlihat. Selain itu frekuensi gambar yang sering muncul di masing-masing pelajaran masih didominasi oleh laki-laki.[] 


\section{Daftar Pustaka}

Achmad, Muthia'in, Bias Gender dalam Pendidikan, Surakarta: UMS Press, 2001.

Amasari, "Pendidikan Berbasis Gender", Laporan Penelitian, Banjarmasin: IAIN Antasari, 2005.

Ansyor, Muhammad dan Nurtain, Pengembangan dan Inovasi Kurikulum, Jakarta: Depdikbud, 1991.

Asroah, Hanum, Sosiologi Pendidikan, cet. I, Surabaya: Kopertais Press, 2008.

Astuti, Mari dkk, Pendidikan Berperspektif Jender Membuka Masa Depan Anak-anak Kita, Yogyakarta: Kanisius, 2006.

Departemen Pendidikan Nasional, Pedoman Penulisan Buku Ajar Berwawasan Gender, Jakarta: Depdiknas, 2003.

Hayat, Bahrul, Sistem Penilaian Buku, Jakarta: Pusat Perbukuan, 2001.

http://www. suarapembaharuan. com/news/2003/22/11/Kesra/Kes02. htm.

Margono, Evaluasi Buku Pelajaran Bahasa Indonesia dan Matematika SD, SMP dan SMA, Laporan hasil penelitian, tidak diterbitkan, STAIN Salatiga, 2002.

Mujiran, Paulus, Pernak-pernik Pendidikan, Manifestasi dalam Keluarga, Sekolah, dan Penyadaran Jender, Jogjakarta: Pustaka Pelajar, 2002.

Peraturan Menteri Pemberdayaan dan Perlindungan Anak Nomor 11 tahun 2010 tentang Pedoman Pelaksanaan Pengarusutamaan Gender di Madrasah Kementerian Agama Republik Indonesia, Jakarta: Berita Negara RI, 2010.

Peraturan Menteri Pendidikan Nasional RI Nomor 2 Tahun 2008 tentang Buku, (Jakarta: Berita Negara RI, 2008)

Peraturan Pemerintah RI No. 28 Tahun 1990 tentang Pendidikan Dasar, Jakarta: Sekneg.

Rafian, "Metodologi Penelitian Komunikasi: Analisis Wacana, Semiotika Framing, Kebijakan Redaksional dan Analisis Korelasional", http:// shindohjourney.wordpress. com. metodologi-penelitian-komunikasi-analisis isi wacana semiotika framing kebijakan redaksional dan analisis korelasional/Rafian's Journey. Diakses tanggal 22 Oktober 2013.

Siti Farikhah, "Bias Gender dalam Pendidikan", Makalah, tidak diterbitkan, STAIN Salatiga, 2000. 
Taya, Paembonan, Penerbitan dan Pengembangan Buku Pelajaran di Indonesia, Jakarta: Depdikbud, 1990.

Undang-Undang Sisdiknas No. 20 tahun 2003, Jakarta: Sekretariat Negara, 2003).

UNICEF, Pendidikan untuk anak perempuan di Indonesia, 2007. 
